\title{
Economic feasibility study of Litopenaeus vannamei shrimp farming: nanobubble investment in increasing harvest productivity
}

\author{
Studi kelayakan ekonomi budidaya udang Litopenaeus vannamei: \\ investasi nanobubble dalam meningkatkan produktivitas hasil panen
}

\author{
Syifa Mauladani ${ }^{1,2}$, Asri Ifani Rahmawati ${ }^{12^{*}}$, Muhammad Fahrurrozi Absirin ${ }^{1,2}$, Arief \\ Hidayatullah $^{1,2}$, Rizki Nugraha Saputra ${ }^{1,2}$, Aprian Fajar Pratama ${ }^{1,2}$, Agus Dwiarto ${ }^{1,2}$, \\ Ahmad Syarif ${ }^{1,2}$, Hardi Junaedi ${ }^{1,3}$, Dedi Cahyadi ${ }^{1,2}$, Henry Kasman Hadi Saputra ${ }^{1,4}$, \\ Wendy Tri Prabowo5, Ujang Komarudin Asdani Kartamiharja ${ }^{5}$, Alfian Noviyanto ${ }^{2,6}$, \\ Nurul Taufiqu Rochman ${ }^{7 *}$
}

\author{
${ }^{1}$ Nanobubble Karya Indonesia, Ltd., South Tangerang, Banten, 15314, Indonesia \\ ${ }^{2}$ Nano Center Indonesia, Jl. Raya Serpong, South Tangerang, Banten, 15314, Indonesia \\ ${ }^{3}$ Department of Agricultural Industry, IPB University, Bogor, West Java, 16680, Indonesia \\ ${ }^{4}$ Department of Aquaculture, Vocational School, IPB University, West Java, 16680, Indonesia \\ ${ }^{5}$ Aquaculture Center for Brackishwater Situbondo, East Java, 68351, Indonesia \\ ${ }^{6}$ Department of Mechanical Engineering, Faculty of Engineering, Mercu Buana University, Jakarta, Indonesia \\ ${ }^{7}$ Research Center for Metallurgy and Materials, Indonesian Institute of Sciences, PUSPIPTEK, Banten, Indonesia \\ "Corresponding author: fani@nano.or.id; nurul@nano.or.id
}

(Received May 13, 2019; Accepted August 5, 2019)

\begin{abstract}
This study aimed to evaluate the economic feasibility of Litopenaeus vannamei shrimp reared at $400 \mathrm{shrimp} / \mathrm{m}^{2}$ in 56 days of culture. The experimental design was set in an $800 \mathrm{~m}^{2} \mathrm{HDPE}$ pond installed with nanobubble and non-nanobubble. Shrimp survival and total harvest in nanobubble treatment were increased to $92 \%$ and $2,255 \mathrm{~kg}$, respectively. Economic parameters calculated in this study were net present value (NPV), internal rate of return (IRR), payback period (PP), break-even point (BEP), benefit-cost ratio (B/C ratio), and sensitivity analysis (SA). The total investment required to run this farming practice is IDR $182,887,700$. Total revenue per cycle is estimated at IDR $157,850,000$ with the selling price of IDR $70,000 / \mathrm{kg}$ of shrimp. The estimated PP is 4 cycles, with an NPV of IDR $172,329,247$ projected in 10 cycles. IRR is estimated at $18 \%$ and BEP is reached after 7,058 $\mathrm{kg}$ production of shrimp. B/C ratio is estimated to be 1.26 and SA showed that productivity is the most affecting parameters in the present analysis. Based on the economic study, vannamei shrimp farming associated with nanobubble system is feasible to be realized.
\end{abstract}

Keywords: economic feasibility, nanobubble, Litopenaeus vannamei, DO concentration

\begin{abstract}
ABSTRAK
Tujuan dari penelitian ini adalah menentukan kelayakan ekonomi usaha budidaya udang Litopenaeus vannamei dengan padat tebar 400 ekor/m² selama 56 hari. Penelitian ini dilakukan pada kolam HDPE berukuran $800 \mathrm{~m}^{2}$ dengan menggunakan nanobubble dan non-nanobubble. Tingkat sintasan udang dan total panen pada kolam nanobubble berturut-turut meningkat mencapai $92 \%$ dan $2.255 \mathrm{~kg}$. Parameter ekonomi yang dihitung terdiri dari net present value (NPV), internal rate of return (IRR), payback period (PP), break-even point (BEP), benefit-cost ratio (B/C ratio), dan sensitivity analysis (SA). Biaya investasi total yang dibutuhkan untuk budidaya ini yaitu $\mathrm{Rp}$ 182.887.700. Pendapatan per siklus diestimasi mencapai Rp 157.850.000 dengan harga jual Rp 70.000 per kg udang. PP diestimasi setelah 4 siklus dengan NPV Rp 172.329.247 diproyeksikan setelah 10 siklus. Nilai IRR diestimasi sebesar 18\% dan BEP diraih setelah produksi udang mencapai $7.058 \mathrm{~kg}$. Rasio B/C diestimasi sebesar 1,26 dan SA menunjukkan bahwa produktivitas merupakan parameter yang paling berpengaruh dalam analisis ini. Berdasarkan hasil studi, budidaya udang menggunakan nanobubble layak diberi investasi.
\end{abstract}




\section{INTRODUCTION}

Shrimp is the main export commodity of Indonesia fishery products in the period of January-September 2018. Shrimp contributed foreign exchange of USD 1.3 billion or $36.96 \%$ of the total export value, whereas when viewed from its volume shrimp only contributed $18.35 \%$ of the total volume of commodities exported. USA, Japan, Netherlands, and China are the main markets for Indonesian shrimp products. The four countries absorbed more than $85.62 \%$ of Indonesian shrimp products (KKP, 2018). Vannamei shrimp Litopenaeus vannamei is one of two shrimp commodities that are the mainstay in the export market. Fast growth, good survival in high stocking densities and wide tolerance to disease make vannamei shrimp the right choice for intensive production (Cuzon et al., 2004; Jaspe et al., 2011). Vannamei are relatively easy to be cultivated, it also makes shrimp farmers in Indonesia have cultivated them in recent years (Suriya et al., 2016).

The obstacle that is often complained by vannamei shrimp farmers is the low quality of fry. According to Ray et al. (2011), the quality of vannamei shrimp has decreased over time, resulting in slow shrimp growth, uneven size, and is very susceptible to environmental changes so the productivity of vannamei cultivation is low. Although the environment of aquaculture fish is a complex system, consisting of several water quality variables, only a few of them play a crucial role. Dissolved oxygen is the most important and critical parameter, requiring continuous monitoring in aquaculture production systems (Boyd, 2017). Overall health and physiological conditions are best if the dissolved oxygen is kept closer to saturation. When the levels are low, the growth of the fish can be highly affected by an increase in stress, tissue hypoxia, and a decrease in swimming activities and a reduction in immunity to diseases (Paschke et al., 2010).

However, there is a great demand to maintain the level of dissolved oxygen at the saturation level which will not affect its physiological or metabolic activities, to produce a high yield in any culture system. A technology that can be applied in overcoming this problem is nanobubble. The application of nanobubble techniques in aquaculture is used to increase the concentration of dissolved gas (oxygen) in the water so that it provides positive effects such as faster fish growth, fish not susceptible to disease and improving water quality (Serizawa, 2017). Nanobubble tends to be stable in the water, this is due to changes in the size of bubbles from micro to nano-size by the diffusion of gas from inside the bubble to the liquid around the bubbles so that the size of the bubbles shrinks to nano size (Meegoda et al., 2018). Electrolyte ions around the bubble will compress the gas molecules around the bubble so that the process of gas diffusion from bubbles to the liquid will be restrained (Tsuge, 2010).

Therefore, the application of nanobubble technology in vannamei shrimp cultivation is expected to increase vannamei shrimp productivity so that it can fit market demand from national to a global scale. The use of nanobubble technology will affect the number of costs, revenues, and benefits from the cultivation business so it needs to calculate its feasibility. This economic analysis aims to determine the viability of vannamei shrimp cultivation using nanobubble at Brackishwater Aquaculture Development Center Situbondo, East Java.

\section{MATERIALS AND METHODS}

The method used in this study is an experimental method that consists of two stages, such as vannamei shrimp cultivation and economic feasibility analysis. Shrimp cultivation was conducted in August to September 2019, while the economic feasibility analysis was conducted in October 2019. This study was conducted at the Brackishwater Aquaculture Development Center Situbondo, East Java.

\section{Vannamei shrimp cultivation}

The stages of vannamei shrimp cultivation included pond preparation and nanobubble installation, frying stock, feed, and water quality monitoring, and ending with harvesting. This study consisted of two treatments, vannamei shrimp cultivation using nanobubble and nonnanobubble as a comparison. Nanobubble is a technology that can increase dissolved oxygen so that shrimp productivity can increase as well. The ponds used in this study were HDPE pond measuring $800 \mathrm{~m}^{2}$ with $1 \mathrm{~m}$ depth. The type of nanobubble was 2 units of Nanobubble BMG 4 installed in one pond. The nanobubble generator was manufactured by Nanobubble Karya Indonesia, Ltd. located at South Tangerang, Banten. Shrimps were in a good quality that was free of pathogens, PL-10, with stocking densities of $400 \mathrm{shrimp} / \mathrm{m}^{2}$. The average initial weight of fry was $0.01 \mathrm{~g}$ and the length was $10 \mathrm{~mm}$. 
The next stage was feeding and water quality monitoring. The feed given was powder shrimp feed containing $40 \%$ protein. The amount of feed given per day was $5 \%$ of vannamei shrimp biomass, while feeding was conducted every three hours. Intensive pond water quality is a very influential factor in the success of aquaculture. Remaining feed and shrimp metabolism will cause accumulation of ammonia levels in the water which if it exceeds the threshold will be toxic. Therefore, routine water quality measurements were carried out every day. The parameters measured consisted of dissolved oxygen (DO), temperature, salinity, $\mathrm{pH}$, and total dissolved solids (TDS).

The last stage in shrimp cultivation was harvesting. In this study, vannamei shrimp was harvested after 56 days of farming, where the size of the shrimp reached $10.1 \mathrm{~g}$ or at size 99 . The harvesting process was carried out in the morning to avoid stress on the shrimp.

\section{Economic feasibility analysis}

Dissolved oxygen levels in shrimp ponds using nanobubble and non-nanobubble were measured during cultivation. Data were analyzed descriptively to find out the best treatment in this study. The best treatment was then calculated using economic feasibility parameters, such as net present value (NPV), internal rate of return (IRR), payback period (PP), break-even point (BEP), benefit-cost ratio (B/C ratio), and sensitivity analysis (SA).

\section{Net present value (NPV)}

Net present value is the present value of net benefits to be obtained in the future and is the difference between the present value of benefits and the present value of costs. NPV measures the increase in net wealth at the moment that would be equivalent to the implementation of the project (Pasqual et al., 2013). Mathematically can be formulated as follows:

Note: $\mathrm{NPV}=$ net present value; $\mathrm{Bt}=$ benefits in

$$
\mathrm{NPV}=\sum_{\mathrm{t}=1}^{\mathrm{n}} \frac{\mathrm{Bt}-\mathrm{Ct}}{1-\mathrm{i}^{\mathrm{t}}}
$$

the $\mathrm{t}$-year; $\mathrm{Ct}=$ costs from in the $\mathrm{t}$-year; $\mathrm{i}=$ interest rates $(14 \%$ per year $) ; t=$ project year.

\section{Internal rate of return (IRR)}

The IRR decision criterion suggests accepting a project if and only if the IRR is greater than the cost of capital and ranking competing projects via their IRRs: the higher a project IRR, the higher its rank (Magni, 2010). IRR is an interest rate that shows the total net present value (NPV) equal to all project costs or NPV equal to zero. Mathematically can be formulated as follows:

Note: IRR = internal rate of return; i' = interest

$$
I R R=i^{\prime}+\left[\frac{N P V^{\prime}}{N P V^{\prime}-N P V^{\prime \prime}}\left(i^{\prime \prime}-i^{\prime}\right)\right]
$$

rates that produce a positive NPV; i" = interest rates that produce negative NPV; NPV' $=\mathrm{NPV}$ at the interest rate $\mathrm{i}^{\prime} ; \mathrm{NPV} "=\mathrm{NPV}$ at the interest rate i".

\section{Payback period (PP)}

Payback period for a capital budgeting project is the length of time it takes for the initial investment to be recouped. The initial investment is recouped from the net proceeds of the operations of the project (Ardalan, 2012). Mathematically can be formulated as follows:

Break-even point (BEP)

$$
\mathrm{PP}=\frac{\text { Investment cost }}{\text { Benefit }} \times 1 \text { year }
$$

Break-even point (BEP) is the production volume at which a firm is neither making profit nor loss. Any increase in production from this level results in profit-making, while any decrease would result in losses. This point is normally illustrated in cost/revenue $(\mathrm{C} / \mathrm{R})$ vs. production level $(\mathrm{Q})$ charts as the position where the total revenue (TR) line intersects the total cost (TC) line (Triyatmo et al., 2016). Mathematically can be formulated as follows:

Benefit-cost ratio (B/C ratio)

$$
\mathrm{BEP}=\frac{\text { Fixed cost }}{\text { Price }- \text { Variable cost }}
$$

$\mathrm{B} / \mathrm{C}$ ratio is a comparison between the level of benefit or income obtained with the total costs incurred. An effort is said to be feasible and gives benefits if the value of $\mathrm{B} / \mathrm{C}$ ratio is greater than zero (0), the greater the value of $\mathrm{B} / \mathrm{C}$ ratio, the greater the benefits to be gained from the business (Llamas \& Herzberg, 2011). Mathematically can be formulated as follows:

Sensitivity analysis (SA)

$$
\mathrm{B} / \mathrm{C} \text { ratio }=\frac{\text { Benefit }}{\text { Total production cost }}
$$


Sensitivity analysis is performed to see the response to changes in prices that occur in production inputs and outputs. This analysis is carried out on rising prices of production materials and decreasing shrimp selling prices by using the switching value method.

\section{RESULTS AND DISCUSSIONS}

\section{Experimental data}

Nanobubble generator, as an additional aerator being installed in vannamei shrimp pond, has managed to improve dissolved oxygen levels throughout the pond. Figure 1 reported the dissolved oxygen levels in the range of $4-8 \mathrm{mg} / \mathrm{L}$ at both treatments, but nanobubble gave a slight improvement on it. Because of its very small size, nanobubble can promote oxygen diffusion in a pond, and hence, showed a result in the escalation of dissolved oxygen (Ebina et al., 2013). Dissolved oxygen is essential in shrimp farming and the most affecting parameter to shrimp physiology. Prolonged exposure to low dissolved oxygen levels could lead to the activation of a shrimp adaptive mechanism (Duan et al., 2013).

Re and Diaz (2011) proven that vannamei shrimp being cultivated in lethal dissolved oxygen
$(2 \mathrm{mg} / \mathrm{L})$ modified its osmoregulation system from isosmotic to hypo-osmotic. Vannamei shrimp started to conduct mixed aerobic and anaerobic metabolism to fulfill the energy demand. Vannamei shrimp in lethal dissolved oxygen exposure would likely use its protein and glycogen as an energy source to produce lactate and glucose. Minimum dissolved oxygen levels could also increase oxygen affinity in blood and lead to the increment of blood $\mathrm{pH}(\mathrm{Re} \& \mathrm{Diaz}$, 2011). Meanwhile, shrimp being cultivated in optimum dissolved oxygen levels ( $>4 \mathrm{mg} / \mathrm{L}$ ) was proven to show a higher growth performance and more resistance to viruses and bacteria (Nonwachai et al., 2011). Ebina et al. (2013) reported an improvement in fish growth (14$59 \%$ ) using nanobubble in 3 weeks of cultivation.

The nanobubble generator application in this present study showed a positive effect on the total harvest, survival rate (SR), and feed conversion ratio (FCR) of vannamei shrimp. Table 1 shows the experimental results of shrimp being cultivated in nanobubble pond as compared to the non-nanobubble. The total harvest of nanobubble pond reached 2,255 kg with SR of 92\% and FCR 1.3 , while the non-nanobubble is only $1,884 \mathrm{~kg}$ with SR of $75 \%$ and FCR 1.4. The high levels

Table 1. Experimental data of vannamei shrimp cultivation using nanobubble

\begin{tabular}{clcc}
\hline No. & \multicolumn{1}{c}{ Parameters } & Nanobubble & Non-nanobubble \\
\hline 1. & Pond area $\left(\mathrm{m}^{2}\right)$ & 800 & 800 \\
2. & Stocking density $\left(\right.$ shrimp $\left./ \mathrm{m}^{2}\right)$ & 400 & 400 \\
3. & Total harvest $(\mathrm{kg})$ & 2,255 & 1,884 \\
4. & Feed conversion ratio & 1.3 & 1.4 \\
5. & Survival rate $(\%)$ & 92 & 75 \\
\hline
\end{tabular}

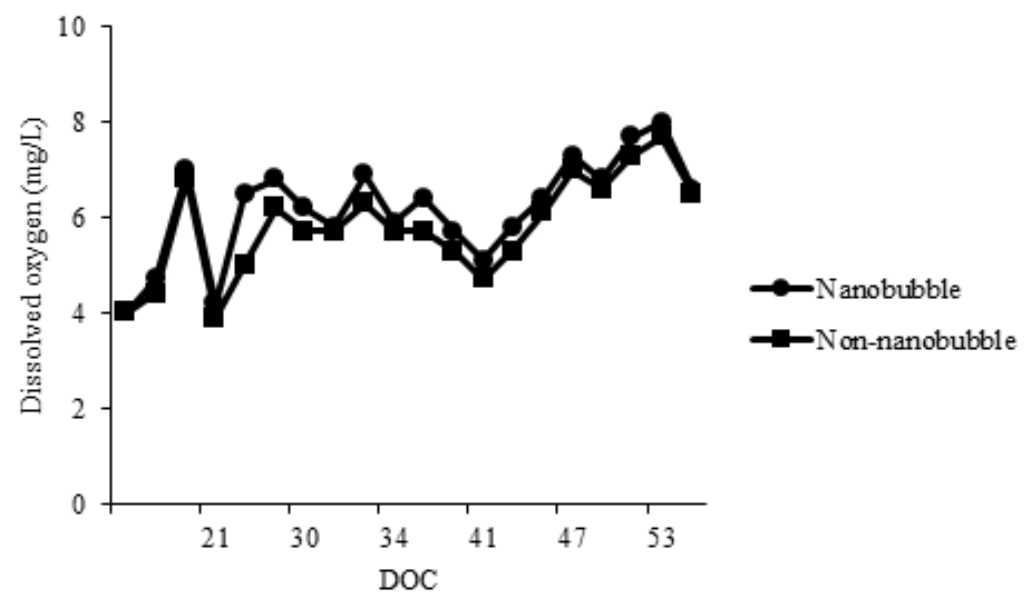

Figure 1. Dissolved oxygen levels in vannamei shrimp pond using nanobubble and non-nanobubble during the cultivation period. 
of oxygen available in the pond are expected to specifically give positive effects to increase shrimp survival, streamline the feed consumption, and enhance harvest as well. As to know that nanobubble has promoted the total harvest to $19.7 \%$ and SR to $17 \%$, further discussion of its economic feasibility is needed.

\section{Economic feasibility analysis}

\section{Capital investment cost}

Capital investment cost incurred in vannamei shrimp cultivation is IDR $182,887,700$. The biggest investment cost was spent on manufacturing Nanobubble BMG 4, which is $60.15 \%$ of all investment costs. Table 2 below shows the investment needed during vannamei shrimp cultivation using nanobubble. The shrimp pond used in this study is the HDPE pond measuring $800 \mathrm{~m}^{2}$.

\section{Raw material cost}

A detail raw material cost is shown in Table 3. The raw material counted as a variable cost because the values depend on the amount of output produced. The components of raw material costs include shrimp larvae, feed, probiotics, vitamins, urea, calcium oxide, TSP, chlorine, and oxygen gas for nanobubble supply. The feed contributed more than $60 \%$ of the total raw material cost. Feed was regularly given per day at the amount of $5 \%$ of biomass for every three hours.

\section{Total production cost}

Total production cost includes variable costs and fixed costs (including depreciation).The total variable cost is IDR $81,129,000$, the total fixed cost is IDR $18,288,770$. Daily freelance of 2 people for 2 months amounting to IDR 6,000,000. The biggest variable cost is spent on feed costs, which is $70 \%$ of the total variable costs. The

Table 2. Capital investment cost of vannamei shrimp cultivation using nanobubble

\begin{tabular}{clcccc}
\hline No. & \multicolumn{1}{c}{ Equipment } & Quantity & Unit & Unit price (IDR) & Total price (IDR) \\
\hline 1. & Nanobubble generator & 2 & units & $55,000,000$ & $110,000,000$ \\
2. & Shrimp pond & 1 & pack & $10,000,000$ & $10,000,000$ \\
3. & Paddlewheel & 6 & units & $6,000,000$ & $36,000,000$ \\
4. & Artesian well & 1 & pack & $5,000,000$ & $5,000,000$ \\
5. & Filtration system & 1 & pack & $5,000,000$ & $5,000,000$ \\
6. & Oxygen tube & 3 & units & $1,000,000$ & $3,000,000$ \\
7. & Profile tank & 1 & unit & $1,000,000$ & $1,000,000$ \\
8. & Electricity installation & 13.3 & kVa & 969,000 & $12,887,700$ \\
\hline Total (IDR) & & & & & $182,887,700$ \\
\hline
\end{tabular}

Table 3. The raw material cost of vannamei shrimp cultivation using nanobubble

\begin{tabular}{clcccc}
\hline No. & Raw material & Quantity & Unit & Unit price (IDR) & Total price (IDR) \\
\hline 1. & Shrimp larvae & 325,000 & shrimp & 45 & $14,625,000$ \\
2. & Shrimp feed & 2,876 & $\mathrm{~kg}$ & 15,000 & $43,140,000$ \\
3. & Probiotic & 4 & pack & $1,000,000$ & $4,000,000$ \\
4. & Vitamin C & 2 & $\mathrm{~kg}$ & 300,000 & 600,000 \\
5. & Urea & 50 & $\mathrm{~kg}$ & 2,000 & 100,000 \\
6. & Calcium oxide & 200 & $\mathrm{~kg}$ & 1,000 & 200,000 \\
7. & TSP & 50 & $\mathrm{~kg}$ & 2,000 & 100,000 \\
8. & Chlorine & 10 & piles & 550,000 & $5,500,000$ \\
9. & Oxygen gas & 14 & tubes & 120,000 & $1,680,000$ \\
\hline Total (IDR) & & \multicolumn{5}{c}{} & $69,945,000$ \\
\hline
\end{tabular}


total production cost as shown in table 4 is IDR $99,417,770$.

Table 4. The total production cost of vannamei shrimp cultivation using nanobubble

\begin{tabular}{llc}
\hline No. & Parameters & Value per cycle (IDR) \\
\hline 1. & Variable cost & \\
a) & Employee wages & $6,000,000$ \\
b) & Raw material & $69,945,000$ \\
c) & Utility (electricity) & $5,184,000$ \\
\hline Total variable cost & $81,129,000$ \\
$2 . \quad$ Fixed cost & \\
a) & Depreciation & $18,288,770$ \\
\hline \multicolumn{2}{l}{ Total fixed cost } & $18,288,770$ \\
Total production cost & $99,417,770$ \\
\hline
\end{tabular}

\section{Revenue}

Revenue obtained in this study comes from the production value of each shrimp size. The price of shrimp for size 99 is IDR 70,000 per $\mathrm{kg}$. Total shrimp harvest production is $2,255 \mathrm{~kg}$. Revenue can be calculated by knowing the total value of shrimp harvest $(\mathrm{kg})$ multiplied by the selling price of shrimp $/ \mathrm{kg}$. The total shrimp harvest is $2,255 \mathrm{~kg}$ multiplied by Rp.70,000/kg. The total receipts in this study were Rp. 157,850,000.

\section{Economic parameters}

Economic parameters calculated in this study are net present value (NPV), internal rate of return (IRR), payback period (PP), breakeven point (BEP), benefit-cost ratio (B/C ratio), and sensitivity analysis (SA). Assumptions are considered as follows.

1. The discount rate is assumed constant at $10.25 \%$ (Bank of Indonesia, 2018)

2. IRR value is evaluated to minimum acceptable rate of return (MARR) at $15 \%$ or 1.46-fold from discount rate; and

3. Depreciation value of the equipment is $10 \%$ per year, and achieved salvage value after 10 years

Table 5 showed the results of the economic feasibility analysis of the present study. The business of shrimp aquaculture is considered feasible if the magnitude of NPV is higher than zero, and vice versa. If the value of NPV is zero means that the returns of business are equivalent to the money invested (Djumanto et al., 2016). NPV of this experiment is projected to reach IDR
$172,329,247$ after 10 cycles. IRR is estimated to be $18 \%$.

Table 5. Economic feasibility analysis of vannamei shrimp cultivation using nanobubble

\begin{tabular}{clc}
\hline No. & \multicolumn{1}{c}{ Parameters } & Value \\
\hline 1. & Net present value (IDR) & $172,329,247$ \\
2. & Internal rate of return (\%) & 18 \\
3. & Break-even point (kg) & 7,058 \\
4. & Payback period (cycle) & 4 \\
5. & B/C ratio & 1.26 \\
\hline
\end{tabular}

The BEP value represents a minimum production of vannamei shrimp to cover all the fixed expenses (Djumanto et al., 2016). BEP could be defined as a point where total expenses and total revenue are equal. Figure 2 shows a break even analysis graph, as could be seen that the minimum production would be at $7,058 \mathrm{~kg}$. The value is summarized in Table 5. The business would likely gain profit after reaching this BEP value.

The payback period is the time needed to return the initial investment in the form of cash flow based on total revenue minus all costs (Djumanto et al., 2016). The minimum time to recover the costs of investment in nanobubble vannamei shrimp pond is expected to be 4 cycles (Figure 3). In other words, shrimp aquaculture using nanobubble may recover the capital after running for 4 cycles. The $\mathrm{B} / \mathrm{C}$ ratio obtained in this study is 1.26 , a value greater than 1 indicates the business is feasible to run.

\section{Sensitivity analysis}

Sensitivity analysis (Figure 4) showed that a $50 \%$ reduction of productivity would increase the total production cost per $\mathrm{kg}(\mathrm{TPC} / \mathrm{kg}$ ) price to $199 \%$ from IDR 43,893 to IDR 87,786. Meanwhile, the $150 \%$ increment of raw materials cost would likely promote $\mathrm{TPC} / \mathrm{kg}$ to $135 \%$. Considering the economic information of business of shrimp aquaculture, three shrimp farming scenarios could be described for nanobubble investment in increasing harvest productivity:

(a) Dynamic. With average utilities and high to utility average and higher profitability, this scenario is directly associated with high productivity levels, so much with relationship to the added value generated by business activities as in their relate monetary of capital and work. 


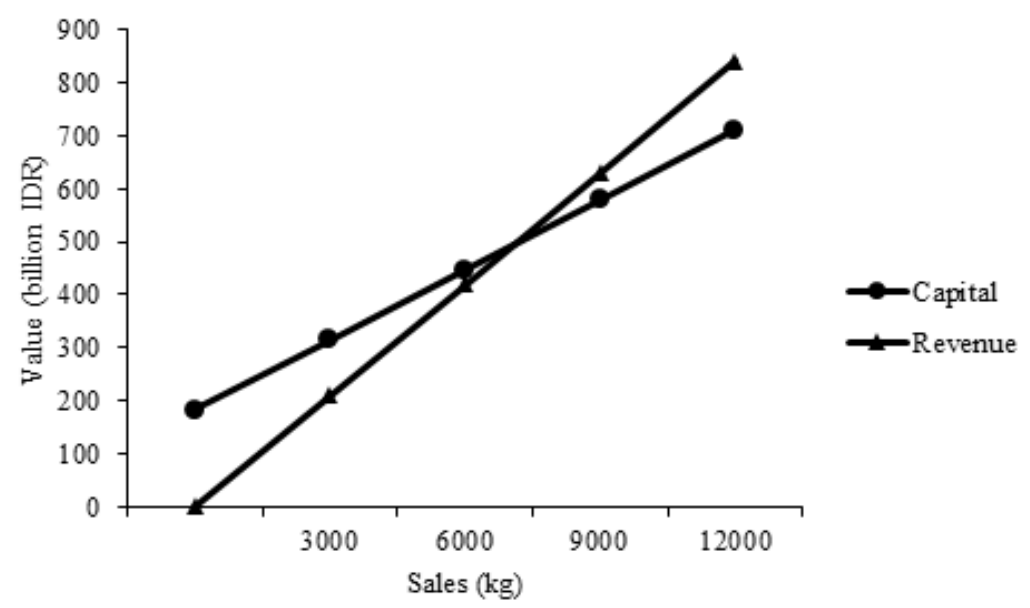

Figure 2. Break-even point curve of vannamei shrimp cultivation using nanobubble

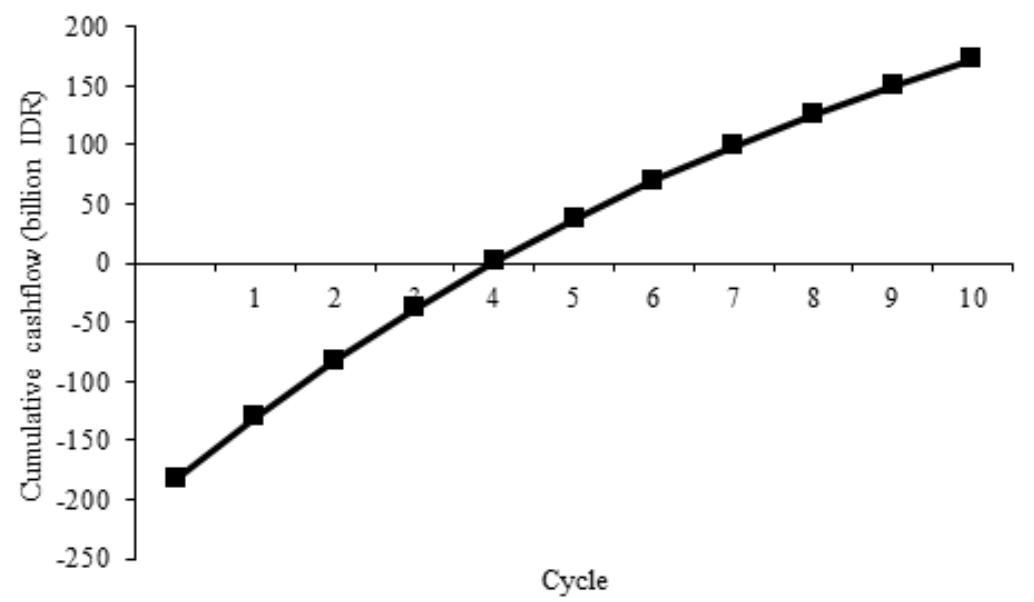

Figure 3. Cumulative cash flow per cycle of shrimp cultivation using nanobubble

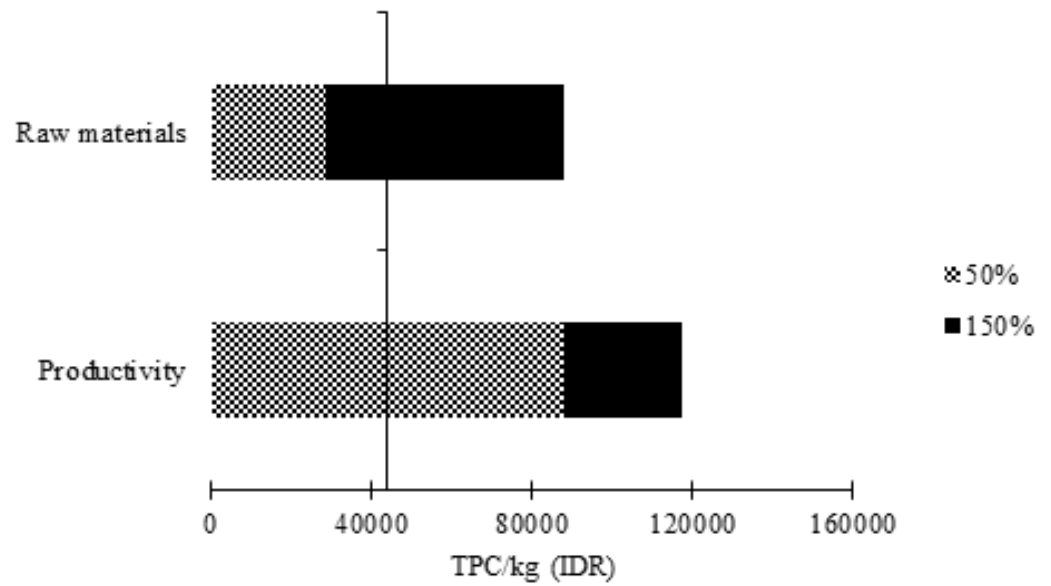

Figure 4. Sensitivity analysis curve of vannamei shrimp cultivation using nanobubble 
(b) Stable. Characterized by high profitability and utility, although in an inferior degree to the shrimp farm in non-nanobubble investment, however, its utility is very superior to the average of the shrimp business venture, as soon as their indicators of productivity show high efficiency in terms of employment and remunerations, nevertheless, it is low for the indicators of productivity of capital, inputs and fixed assets.

(c) Decadent scenario. Non-nanobubble investment of shrimp aquaculture presents to show the lower economic parameters, with lower levels in profitability and losses in shrimp farm operation which is reflected in poor performance in terms of productivity.

\section{CONCLUSION}

The present finding shows that nanobubble could slightly increase the dissolved oxygen throughout the pond, and give a beneficial impact to the total harvest, SR, and FCR. The total harvest of nanobubble pond reached 2,255 kg with SR of $92 \%$ and FCR 1.3, while the non-nanobubble is only $1,884 \mathrm{~kg}$ with SR of $75 \%$ and FCR 1.4 , hence, total harvest and SR are increased to 19\% and $17 \%$, respectively. Economic parameters calculated by NPV, IRR, BEP, PP, and B/C ratios are accounted to be IDR $172,329,247$ projected in 10 cycles, $18 \%, 7,058 \mathrm{~kg}, 4$ cycles and 1.26 , sequentially. Afterward, the next 6 cycles will be a considerable benefit for shrimp farmers using nanobubble technology. To minimize the potential for loss, nanobubble farms should target a minimum acceptable yield that would vary with farm size. However, further research is needed on the extent to which management can reduce risk of shrimp mortality by investing in such premium quality inputs, but the most important is the perspective of an integral approach to sustainability.

\section{ACKNOWLEDGMENTS}

This research was funded by grants from the Demand-Driven Research (DDR) Coral Reef Rehabilitation and Management Prog (COREMAP) - Coral Triangle Initiative (CTI) 2018-2019 by Oceanography Research Center,
Indonesian Institute of Sciences (LIPI). Mr. Hardi Junaedi was supported by a scholarship from Indonesia Endowment Fund for Education (LPDP).

\section{REFERENCES}

Ardalan K. 2012. Payback period and NPV: their different cash flows. Journal of Economics and Finance Education 11: 10-16.

Boyd CE. 2017. General relationship between water quality and aquaculture performance in ponds. Fish Diseases, 147-166.

Cuzon G, Lawrence A, Gaxiola G, Rosas C, Guillaume J. 2004. Nutrition of Litopenaeus vannamei reared in tanks or in ponds. Aquaculture 235: 513-551.

Djumanto, Ustadi, Rustadi, Bambang T. 2016. Feasibility study of the profitability of vannamei shrimp aquaculture on coastal area of Keburuhan Village, Purworejo Regency. Aquacultura Indonesiana 17: 7-11.

Duan Y, Zhang X, Liu X, Thakur DN. 2014. Effect of dissolved oxygen on swimming ability and physiological response to swimming fatigue of whiteleg shrimp Litopenaeus vannamei. Journal of Ocean University of China 13: 132-140.

Ebina K, Shi K, Hirao M, Hashimoto J, Kawato Y, Kaneshiro S, Morimoto T, Koizumi K, Yoshikawa H. 2013. Oxygen and air nanobubble water solution promote the growth of plants, fishes, and mice. PLoS ONE 8: 1-7.

[Kemeterian Kelautan dan Perikanan] KKP. 2018. Laporan Kinerja Triwulan III Tahun 2018. Jakarta, Indonesia: KKP.

Jaspe CJ, Caipang CMA, Elle BJG. 2011. Modified extensive pond culture of Litopenaeus vannamei for sustainable shrimp culture in Philippines. AES Bioflux 3: 44-52.

Llamas AH, Herzberg MZ. 2011. Bioeconomic modeling and risk analysis of raising shrimp Litopenaeus vannamei in floating cages in northwestern Mexico: Assessment of hurricane hazard, stochastic variability of shrimp and feed prices, and zootechnical parameters. Aquaculture 314: 261-268.

Magni CA. 2010. Average internal rate of return and investment decisions: a new perspective. The Engineering Economist 55: 150-180. 
Meegoda JN, Hewage SA, Batagoda JH. 2018. Stability of nanobubbles. Environmental Engineering Science 35: 1216-1227.

Nonwachai T, PurivirojkuW, Chuchird N, Limsuwan C. 2011. Effects of dissolved oxygen levels on growth, survival, and immune response of juvenile Pacific white shrimp Litopenaeus vannamei. Journal of Fisheries and Environment 35: 1-10.

Paschke K, Cumillaf JP, Loyola S, Gebauer P, Urbina M, Chimal ME, Pascual C, Rosas C. 2010. Effect of dissolved oxygen level on respiratory metabolism, nutritional physiology, and immune condition of southern king crab Lithodes santolla (Molina, 1782) (Decapoda, Lithodidae). Marine Biology 157: 7-18.

Pasqual J, Padilla E, Jadotte E. 2013. Technical note: Equivalence of different profitability criteria with the net present value. International Journal of Production Economics 142: 205210.

Ray AJ, Dillon KS, Lotz JM. 2011. Water quality dynamics and shrimp Litopenaeus vannamei production in intensive, mesohaline culture systems with two levels of biofloc management. Aquacultural Engineering 45: 127-136.
Re AD, Diaz F. 2011. Effect of different oxygen concentration on physiological energetics of bliue shrimp, Litopenaeus stylirostris (Stimpson). The Open Zoology Journal 4: $1-18$.

Serizawa A. 2017. Fundamentals and applications of micro/nano bubbles. International Symposium on Application of High Voltage, Plasmas and Micro/Nano Bubbles to Agriculture and Aquaculture, 5-7 January 2017. Rajamangala University of Technology Lanna Chiang Mai, Thailand.

Suriya M, Shanmugasundaram S, Mayavu P. 2016. Stocking density, survival rate, and growth performance of Litopenaeus vannamei (Boon, 1931) in different cultured shrimp farms. International Journal of Current Research in Biology and Medicine 1: 26-32.

Triyatmo B, Suadi, Ambarwati D, Sukardi. 2016. Technical and financial aspects of white shrimp Litopenaeus vannamei culture in coastal sandy soil area of Bantul regency. Aquaculturana Indonesiana 17: 54-59.

Tsuge H. 2010. Fundamentals of microbubbles and nanobubbles. Bulletin of The Society of Sea Water Science Japan 64: 4-10. 